\title{
PENGARUH SUPLEMENTASI ZAT GIZI MIKRO TERHADAP STATUS BESI DAN STATUS VITAMIN A PADA SISWA SLTP
}

\author{
Dewi Permaesih ${ }^{1}$; Fitrah Ernawati'; Endi Ridwan ${ }^{1}$; Sihadi'; dan Sukati Saidin ${ }^{1}$ \\ ${ }^{1}$ Pusat Penelitian dan Pengembangan Gizi dan Makanan
}

\begin{abstract}
ABSTRAK
Penelitian status gizi siswa sekolah lima tahun terakhir mengungkapkan bahwa prevalensi anemia, yang dapat menyebabkan turunnya konsentrasi belajar, dan kurang vitamin A, yang dapat menyebabkan turunnya daya tahan tubuh, masih cukup tinggi, sehingga menjadi kendala dalam upaya mengoptimalkan prestasi belajar. Keadaannya semakin buruk jika kedua masalah ini diderita secara bersama-sama oleh siswa. Penelitian ini bertujuan untuk mengetahui dampak suplementasi zat gizi mikro (Fe dan Vitamin A) terhadap perbaikan status besi dan status vitamin A. Penelitian dilaksanakan pada 150 siswa anemia yang tinggal di kabupaten Bogor. Data yang dikumpulkan meliputi: identitas siswa, kadar $\mathrm{Hb}$, s-transferin, vitamin A serum (retinol), konsumsi makanan/zat gizi dan energi. Sebelum pemberian suplemen, dilakukan "deworming" dengan pemberian obat cacing dosis tunggal "Combantrin". Sampel dibagi tiga kelompok, masing-masing 50 siswa. Pada kelompok A setiap siswa mendapat satu pil besi (ferro sulfat) dengan dosis $60 \mathrm{mg}$ besi elemental $+0,25 \mathrm{mg}$ asam folat dan kapsul vitamin A (10.000 SI) dua kali per minggu. Kelompok $B$ hanya mendapat satu pil besi seperti pada kelompok A, diberikan dua kali per minggu. Kelompok $\mathrm{C}$ adalah kelompok pembanding yang mendapat plasebo. Suplementasi berlangsung selama 12 minggu. Pemberian suplemen satu pil besi ( $60 \mathrm{mg}$ besi elemental $+0,25 \mathrm{mg}$ asam folat) dan vitamin A (10.000 SI) disertai pemberian snack mengandung energi (15\% AKG), dua kali per minggu selama 12 minggu dapat memeningkatkan kadar $\mathrm{Hb}$ sebesar 1,40 $\mathrm{g} / \mathrm{dl}$, serum transferrin receptor (sTFR) sebesar - 1,0 $\mu \mathrm{g} / \mathrm{L}$, serum vitamin A (retinol) sebesar 6,1 $\mu \mathrm{g} / \mathrm{dl}$. Tidak ada perbedaan bermakna konsumsi zat gizi (energi dan protein) sebelum dan sesudah pemberian suplementasi.
\end{abstract}

Kata kunci: vitamin A, zat besi, siswa, anemia, KVA

\section{ABSTRACT}

\section{THE IMPACT OF MICRONUTRIENT SUPPLEMENTATION ON THE NUTRITION STATUS} OF Fe AND VITAMIN A OF SCHOOL CHILDREN

Research on nutritional status of school children in the last five years revealed that prevalence of anemia, which was able to decrease the learning concentration of children, and vitamin A deficiency, which could reduce the children immunity, considered as constraints in optimalizing students learning performance. The condition could be worse when students suffered of these 2 problems. This study was aimed to find out the impact of micronutrient supplementation (Fe and Vitamin A) on Fe and Vitamin A status of the school children. The sample of the study consisted of 150 anemia students lived in the municipality of Bogor. Data collected were child identity, haemoglobin level, serum transferin, vitamin A serum (retinol), and data on dietary intake of some nutrients and energy. Before supplementation was given, children received deworming with single dose of Combatrin. Samples were divided into 3 groups, each group consisted of 50 students. Supplementation had been given for 12 weeks, with the arrangement as follows: 1) In a Group $A$, each student received one iron pill (ferrous sulphate) with the dosage of $60 \mathrm{mg}$ elemental iron $+0.25 \mathrm{mg}$ of folic acid and capsule of vitamin $A(10,000 \mathrm{IU})$ twice a week, 2)In a Group B, each student only received one iron pill similar to the Group A, twice a week, and 3) In a Group C, the group received a placebo. Supplementation of iron pill ( $60 \mathrm{mg}$ elemental iron $+0.25 \mathrm{mg}$ of folic acid) and vitamin $A(10,000$ IU) added with snack which had energy equal to $15 \%$ of RDA for 12 weeks, could improve the haemoglobin level up to $1.40 \mathrm{~g} / \mathrm{dl}$, serum transferin receptor (STFR) up to $1.0 \mu \mathrm{g} / \mathrm{dl}$. There was no siginificant difference of energy and protein intakes before and after supplementation.

Keywords: vitamin A, iron, student, anemia, vitamin A deficiency

\section{PENDAHULUAN}

A nak sekolah merupakan sumber daya manusia (SDM) generasi penerus bangsa yang potensinya perlu terus dibina dan dikembangkan. Kualitas SDM ditentukan oleh dua faktor yang saling berhubungan, yaitu pendidikan dan kesehatan. Status gizi dan kesehatan merupakan prakondisi utama yang harus dipenuhi untuk keberhasilan upaya 
pendidikan. Beberapa hasil penelitian mengungkapkan sebagian anak sekolah masih mengalami berbagai masalah kurang gizi. ${ }^{1,2}$

Hasil penelitian Saidin, $2009^{3}$ menemukan prevalensi anemia pada anak remaja SMP di perdesaan masih cukup tinggi sebesar 26,5 persen. Dampak anemia pada kalangan pelajar sangat merugikan karena membuat lesu, lemah, semangat belajar menurun, rentan terhadap penyakit sehingga berakibat konsentrasi dan prestasi belajar menurun.

Selain anemia pada anak sekolah ditemukan juga masalah defisiensi vitamin A. Gambaran terakhir besarnya masalah defisiensi vitamin A (kadar retinol<20 ug/dl) dari penelitian Saidin sebesar 28,9 persen. Hasil penelitian Wiryatmaji B, $2007^{4}$ kadar serum vitamin $A<20$ ug/dl pada anak sekolah sebesar 24 persen. Hasil penelitian yang dilakukan oleh Ke Chen et al. (2009) pada anak berumur 2-7 tahun menunjukkan anak dengan Kurang Vitamin $A$ secara bermakna berisiko lebih tinggi untuk menderita anemia (OR=2.56; $\mathrm{Cl} 95 \%$ : 1.155.70). ${ }^{5}$ Menurut Gamble, et al. $(2004)^{6}$, kekurangan vitamin $\mathrm{A}$ dan kurang zat besi merupakan faktor penyebab terjadinya anemia. Terdapat hubungan yang erat antara vitamin A dan indikator metabolisme zat besi. Pada anak yang kurang vitamin $A$ dan zat besi pemberian vitamin $A$ akan memobilisasi cadangan zat besi untuk meningkatkan erythropoiesis, dengan meningkatkan sirkulasi erythropoietin ${ }^{7}$. Kondisi ini berpengaruh terhadap pembentukan haemoglobin $(\mathrm{Hb})$. Bila terjadi kekurangan akan menyebabkan terganggunya metabolisme dan kekurangan vitamin $\mathrm{A}$ dan juga dapat menurunkan kekebalan tubuh terhadap penyakit infeksi. ${ }^{7}$

Salah satu penyebab tingginya prevalensi anemia dan masalah kurang vitamin $\mathrm{A}(\mathrm{KVA}) \mathrm{di}$ Indonesia adalah masih rendahnya konsumsi zat besi dan retinol dalam makanan sehari-hari. Saidin, $2009^{3}$ menemukan bahwa konsumsi zat besi dan retinol pada remaja masing-masing sebesar 40 persen dan 50 persen dari angka kecukupan yang dianjurkan (RDA). Oleh karena itu diperlukan tambahan (suplemen) asupan untuk memenuhi defisit kedua zat gizi mikro tersebut. Untuk mengoptimalkan pembentukan $\mathrm{Hb}$ diberikan penambahan vitamin A pada saat suplementasi pil zat besi pada anak sekolah SLTP.

\section{METODE PENELITIAN}

Penelitian ini menggunakan disain kuasi eksperimen. Populasi penelitian adalah murid SLTP kelas 8 dan 9. Sedangkan sampel penelitian adalah murid SLTP kelas I dan II yang memenuhi kriteria inklusi yaitu: umur 12 15 tahun, sehat secara pemeriksaan klinis,tidak menderita penyakit kronis, kadar $\mathrm{Hb}$ antara 8 sampai $11,9 \mathrm{~g} / \mathrm{dl}$ dan bersedia berpartisipasi dalam penelitian. Dari perhitungan besar sampel didapatkan 50 sampel per kelompok. ${ }^{8}$

\section{Lokasi dan Waktu Penelitian}

Penelitian dilakukan di wilayah kabupaten Bogor di dua SLTP di kecamatan Sukaraja dan Rancabungur. Pelaksanaan penelitian berlangsung selama 8 bulan pada tahun 2010 .

\section{Cara Pengambilan Sampel}

Pemilihan SLTP dilakukan secara purposive berdasarkan hasil penelitian Saidin, 2009. Terhadap semua anak kelas 1 dan 2 dari SLTP terpilih dilakukan pemeriksaan kadar $\mathrm{Hb}$ untuk mencari 150 anak penderita anemia, dan secara random akan dibagi menjadi tiga kelompok penelitian. Kelompok $A$ (50 orang), kelompok B (50 orang), dan kelompok C (50 orang). Kemudian kepada seluruh anak diberikan obat cacing Albendazole dosis tunggal. Selanjutnya mulai dilakukan suplementasi selama 12 minggu. Kelompok $A$ mendapat tablet besi dengan dosis $60 \mathrm{mg}$ dan kapsul vitamin A dengan dosis 10.000 S.I. per orang dua kali per minggu. Kelompok $B$ mendapat satu pil besi (ferro sulfat) dengan dosis $60 \mathrm{mg}$ besi elemental + 0,25 $\mathrm{mg}$ asam folat setiap orang dua kali per minggu. Kelompok $\mathrm{C}$ adalah kelompok pembanding yang mendapat plasebo. Pemberian pil zat besi dilakukan di sekolah oleh guru. Masing-masing kelompok sebelum memperoleh zat besi telah diberikan makanan snack sebagai tambahan energi (15\% AKG). Setelah tiga bulan intervensi dilakukan pemeriksaan evaluasi dengan pengukuran berat badan dan tinggi badan, pemeriksaan kadar $\mathrm{Hb}$, trasferin, vitamin $\mathrm{A}$ dalam serum dan pengukuran konsentrasi belajar. Data penting yang akan dikumpulkan adalah data cakupan konsumsi tablet besi dan kapsul vitamin A masing-masing anak yang setiap minggu dengan cara absensi. 
Data lain yang akan dikumpulkan adalah konsumsi zat gizi dengan metoda recall $2 \times 24$ jam, pola konsumsi makanan dengan metode FFQ (Food Frequency Questionaire), riwayat penyakit dan kejadian sakit (morbiditas). Data morbiditas akan dikumpulkan dengan cara wawancara oleh peneliti.

Pengumpulan data meliputi:

1. Data identitas murid termasuk pendidikan dan pekerjaan orang tua, jumlah aggota dalam rumah tangga, kesehatan lingkungan yang akan dikumpulkan dengan cara wawancara.

2. Data klinis untuk menetapkan status kesehatan dilakukan oleh dokter dengan mengisi formulir yang telah tersedia.

3. Data status gizi berdasarkan antropometri (berat badan dan tinggi badan) oleh tenaga terlatih dari Puslitbang Gizi dan Makanan.

4. Data $\mathrm{Hb}$ dianalisis dengan metoda "Cyanmethemoglobin", kadar tansferin dengan metoda "ELIZA" dan kadar vitamin A dengan metoda HPLC.

5. Data konsumsi makanan dilakukan dengan metoda "Recall" 2x 24 jam.

6. Data cakupan konsumsi pil zat besi dan Vitamin A dikumpulkan dengan cara absensi setiap kali minum oleh peneliti atau guru.

\section{Manajemen dan analisis data}

Manajemen data meliputi kegiatan editing, entri dan cleaning data sebelum dilakukan analisis. Analisis data ditujukan untuk mencapai tujuan penelitian. Data disajikan dalam bentuk rata-rata, simpang baku, sebaran, uji statistik yang akan digunakan adalah uji bivariat dan Anova.

\section{HASIL}

\section{Karakteristik Sampel}

Hasil pengumpulan data identitas atau karakteristik sampel disajikan pada Tabel 1 dan Tabel 2. Umur sampel berkisar antara 11-15 tahun, berat badan antara $25,3-56,7 \mathrm{~kg}$ dan tinggi badan antara 127,6 - 162,8 cm dan IMT berkisar $14,0-24,3 \mathrm{~kg} / \mathrm{m}^{2}$. Rerata umur sampel untuk ketiga kelompok penelitian hampir sama, masing-masing sebesar 13,4 $\pm 0,88$ thn, 13,7 \pm 0,75 thn dan $13,6 \pm 1,06$ thn. Rerata Indeks Massa Tubuh (IMT) sebagai gambaran simpanan lemak untuk ketiga kelompok penelitian juga hampir sama (Tabel 1).

Tabel 1

Karakteristik Sampel menurut Kelompok

\begin{tabular}{lccc}
\hline \multirow{2}{*}{ Variabel } & \multicolumn{3}{c}{ Kelompok } \\
\cline { 2 - 4 } & A & B & C \\
\cline { 2 - 4 } & Rerata \pm SD & Rerata \pm SD & Rerata \pm SD \\
\hline Umur (tahun) & $13,4 \pm 0,88$ & $13,7 \pm 0,75$ & $13,6 \pm 1,06$ \\
Berat Badan $(\mathrm{Kg})$ & $37,5 \pm 7,02$ & $37,2 \pm 6,34$ & $38,1 \pm 6,86$ \\
Tinggi Badan $(\mathrm{Cm})$ & $146,8 \pm 7,89$ & $146,2 \pm 6,89$ & $146,7 \pm 7,79$ \\
IMT $\left(\mathrm{kg} / \mathrm{m}^{2}\right)$ & $17,3 \pm 1,91$ & $17,3 \pm 1,92$ & $17,6 \pm 2,36$ \\
\hline
\end{tabular}

Dari Tabel 2 terlihat bahwa pendidikan orang tua sampel cukup rendah, sebagian besar ibu hanya lulus sekolah dasar sebesar 71-79 persen. Presentase ibu lulus SD untuk ketiga kelompok penelitian hampir sama masing-masing sebesar 78,7 persen, 71,1 persen dan 74,5 persen. Urutan kedua adalah lulus SMP masing-masing sebesar 10,6 persen, 13,3 persen dan 10,6 persen. menurut variabel pendidikan bapak, urutan pertama adalah lulus SD masing-masing sebesar 70,2 persen, 62,2 persen dan 59,6 persen, untuk urutan kedua juga lulus SMP, masing-masing sebesar 21,3 persen, 20,0 persen dan 23,4 persen untuk kelompok $\mathrm{A}, \mathrm{B}$ dan $\mathrm{C}$.

Pekerjaan ibu sebagian besar adalah ibu rumah tangga, kelompok A sebesar 85,2 persen, kelompok $B$ sebesar 82,2 persen dan kelompok C sebesar 85,2 persen. Pekerjaan bapak sebagian besar adalah buruh dengan pendapatan tidak tetap. Kelompok $A$ sebesar 44,7 persen, kelompok B sebesar 44,5 persen dan kelompok $C$ sebesar 42,6 persen. Urutan kedua adalah pedagang masing-masing sebesar 23,4 persen, 22,2 persen dan 19,1 persen. 
Tabel 2

Karakteristik Orang Tua Sampel menurut Kelompok

\begin{tabular}{|c|c|c|c|c|c|c|}
\hline \multirow{2}{*}{ Pendidikan lbu } & \multicolumn{2}{|c|}{ A } & \multicolumn{2}{|c|}{ B } & \multicolumn{2}{|c|}{ C } \\
\hline & $\mathrm{n}$ & $\%$ & $\mathrm{n}$ & $\%$ & $\mathrm{n}$ & $\%$ \\
\hline 1.Tidak sekolah dan tidak tamat SD & 4 & 8,5 & 6 & 13,3 & 5 & 10,6 \\
\hline 2.Tamat SD & 37 & 78,7 & 32 & 71,1 & 35 & 74,5 \\
\hline 3.Tamat SMP & 5 & 10,6 & 6 & 13,3 & 5 & 10,6 \\
\hline \multirow[t]{2}{*}{ 4.Tamat SMA, D3 } & 1 & 2,1 & 1 & 2,2 & 2 & 4,3 \\
\hline & 47 & 100,0 & 45 & 100,0 & 47 & 100,0 \\
\hline \multirow{2}{*}{ Pendidikan Bapak } & \multicolumn{2}{|c|}{ A } & \multicolumn{2}{|c|}{ B } & \multicolumn{2}{|c|}{ C } \\
\hline & $\mathrm{n}$ & $\%$ & $\mathrm{n}$ & $\%$ & $\mathrm{n}$ & $\%$ \\
\hline 1.Tidak sekolah dan tidak tamat SD & 3 & 6,4 & 6 & 13,3 & 6 & 12,8 \\
\hline 2.Tamat SD & 33 & 70,2 & 28 & 62,2 & 28 & 59,6 \\
\hline 3.Tamat SMP & 10 & 21,3 & 9 & 20,0 & 11 & 23,4 \\
\hline \multirow[t]{2}{*}{ 4.Tamat SMA, D3 } & 1 & 2,1 & 2 & 4,5 & 2 & 4,2 \\
\hline & 47 & 100,0 & 45 & 100,0 & 47 & 100,0 \\
\hline \multirow{2}{*}{ Pekerjaan Ibu } & \multicolumn{2}{|c|}{ A } & \multicolumn{2}{|c|}{ B } & \multicolumn{2}{|c|}{ C } \\
\hline & $\mathrm{n}$ & $\%$ & $\mathrm{n}$ & $\%$ & $\mathrm{n}$ & $\%$ \\
\hline 1.Tidak bekerja & 40 & 85,2 & 37 & 82,2 & 40 & 85,2 \\
\hline 2.Pegawai Negeri/Swasta & 1 & 2,1 & 2 & 4,4 & 1 & 2,1 \\
\hline 3.Buruh & 2 & 4,3 & 3 & 6,7 & 2 & 4,3 \\
\hline \multirow[t]{2}{*}{ 4.Pedagang } & 4 & 8,4 & 3 & 6,7 & 4 & 8,4 \\
\hline & 47 & 100,0 & 45 & 100,0 & 47 & 100,0 \\
\hline \multirow{2}{*}{ Pekerjaan Bapak } & \multicolumn{2}{|c|}{ A } & \multicolumn{2}{|c|}{ B } & \multicolumn{2}{|c|}{ C } \\
\hline & $\mathrm{n}$ & $\%$ & $\mathrm{n}$ & $\%$ & $\mathrm{n}$ & $\%$ \\
\hline 1.Tidak bekerja & 2 & 4,2 & 2 & 4,4 & 3 & 6,4 \\
\hline 2.Pegawai Negeri/Swasta & 7 & 14,9 & 8 & 17,8 & 7 & 14,9 \\
\hline 3.Buruh & 21 & 44,7 & 20 & 44,5 & 20 & 42,6 \\
\hline 4.Pedagang & 11 & 23,4 & 10 & 22,2 & 9 & 19,1 \\
\hline 5.Petani & 3 & 6,4 & 2 & 4,4 & 3 & 6,4 \\
\hline \multirow[t]{2}{*}{ 6.Sopir } & 3 & 6,4 & 3 & 6,7 & 5 & 10,6 \\
\hline & 47 & 100,0 & 45 & 100,0 & 47 & 100,0 \\
\hline
\end{tabular}

\section{Cakupan Konsumsi Pil Zat Besi dan Vitamin A}

Hasil pengumpulan data cakupan konsumsi yang menunjukkan kepatuhan minum suplemen menunjukkan bahwa rerata jumlah pil zat besi dan vitamin $A$ yang diminum kelompok $A$ sebesar $19 \pm 2,1$ pil $(79,2 \%)$, kelompok B sebanyak $20 \pm 3,2$ pil $(83,3 \%)$ dan kelompok C yang memperoleh pil placebo sebesar $19 \pm 3,6$ pil $(79,2 \%)$. Dengan demikian jumlah zat besi yang dikonsumsi oleh kelompok $A$ yang berasal dari suplementasi sebesar 19 pil x $60 \mathrm{mg} / 12$ minggu $=95 \mathrm{mg} /$ minggu $\infty 13,6 \mathrm{mg} / \mathrm{hari}$.

Bila kecukupan zat gizi yang dianjurkan untuk anak remaja sebesar $14 \mathrm{mg}$, maka jumlah zat besi yang diperoleh dari suplementasi sudah terpenuhi. Selain pil zat besi kelompok A juga memperoleh satu kapsul vitamin A dengan dosis 10000 IU, maka jumlah Vitamin A yang diperoleh dari suplementasi sebesar $19 \times 10000$ IU/ 12 minggu $=15833 \mathrm{lU} /$ minggu $\infty 678 \mathrm{RE}$. Bila kecukupan vitamin A untuk anak remaja yang dianjurkan sebesar $500 \mathrm{RE}$, maka jumlah vitamin $A$ yang diperoleh dari suplementasi sudah terpenuhi. Kelompok B yang hanya memperoleh pil zat besi saja memperoleh zat besi dari suplementasi sebesar 20 pil $\times 60 \mathrm{mg} /$ 12 minggu $=100 \mathrm{mg} /$ minggu $\infty 14,3 \mathrm{mg} /$ hari. Seperti kelompok $A$, jumlah zat besi yang diterima dari suplementasi untuk B sudah terpenuhi. 


\section{Data Biokimia Sebelum dan Sesudah Intervensi}

Pemeriksaan kadar $\mathrm{Hb}$ dan konsentrasi belajar dilakukan terhadap semua anak. Pada awalnya masing-masing kelompok ada 50 anak. Setelah evaluasi sebanyak 11 anak tidak mengikuti sampai evaluasi kedua, sehingga jumlah anak yang mempunyai data lengkap untuk kelompok $A$, B dan $C$ tinggal 47,45 dan 47 anak. Tidak semua sampel dianalisa kadar transferin dan vitamin A masing-masing hanya dianalisis 75 persen dan 60 persen.

Hasil pengumpulan data utama seperti kadar $\mathrm{Hb}$, serum transferin, vitamin $\mathrm{A}$, dan konsentrasi belajar sebelum intervensi disajikan pada Tabel 3, 4, 5 dan 6 .

Tabel 3

Rata-rata Kadar Hb Sebelum Intervensi menurut Kelompok

\begin{tabular}{ccccc}
\hline \multirow{2}{*}{ Kelompok } & $\mathrm{n}$ & \multirow{2}{*}{$\begin{array}{c}\text { Rerata } \pm \mathrm{SD} \\
(\mathrm{g} / \mathrm{dl})\end{array}$} & \multicolumn{2}{c}{ Nilai } \\
\cline { 4 - 6 } & & $11,3 \pm 0,97$ & 9,3 & 12,5 \\
\hline A & 47 & $11,4 \pm 0,91$ & 9,0 & 12,5 \\
B & 45 & $11,3 \pm 0,89$ & 9,3 & 12,6 \\
C & 47 & & & \\
\hline
\end{tabular}

Dari Tabel 3 tampak bahwa rerata kadar $\mathrm{Hb}$ sampel untuk masing-masing kelompok tidak berbeda. Kelompok $A$ sebesar 11,3 $\pm 0,97$ $\mathrm{g} / \mathrm{dl}$, kelompok B sebesar 11,4 $\pm 0,91 \mathrm{~g} / \mathrm{dl}$ dan $11,3 \pm 0,89 \mathrm{~g} / \mathrm{dl}$. Rerata kadar $\mathrm{Hb}$ sebelum intervensi tidak menunjukkan perbedaan yang bermakna $(F=0,035$, Sign= 0,965). Angka ini menunjukkan bahwa keadaan status $\mathrm{Hb}$ layak untuk dibandingkan. Bila terjadi perbedaan pada akhir penelitian merupakan akibat dari intervensi.

Indikator status besi selain kadar $\mathrm{Hb}$, dianalisis juga kadar Transferin yang jenuh dengan ion besi yang disebut s.Transferin (sTFR). Rata-rata kadar sTFR disajikan pada Tabel 4.

Tabel 4

Rata-rata Kadar Transferin dalam Darah menurut Kelompok

\begin{tabular}{ccccc}
\hline Kelompok & $\mathrm{n}$ & Rerata \pm SD & \multicolumn{2}{c}{ Nilai } \\
\cline { 4 - 5 } & & & Min & Max \\
\hline A & 36 & $2,15 \pm 0,657$ & 1,09 & 4,72 \\
B & 39 & $2,25 \pm 0,747$ & 1,04 & 3,93 \\
C & 37 & $2,12 \pm 0,577$ & 1,19 & 3,8 \\
\hline
\end{tabular}

Dari Tabel 4 terlihat bahwa rerata kadar transferin dalam darah pada awal penelitian untuk ketiga kelompok ( $\mathrm{A}, \mathrm{B}$ dan $\mathrm{C}$ ) tidak menunjukkan perbedaan yang bermakna ( $\mathrm{F}=$ 0,412, Sign= 0,663). Masing-masing sebesar
$2,15 \pm 0,657 \mu \mathrm{g} / \mathrm{L}, 2,25 \pm 0,747 \mu \mathrm{g} / \mathrm{L}$ dan 2,12 $\pm 0,577 \mu \mathrm{g} / \mathrm{L}$.

Rerata kadar vitamin A sebelum intervensi menurut kelompok penelitian disajikan pada Tabel 5. 
Tabel 5

Rata-rata Kadar Vitamin A Sebelum Intervensi menurut Kelompok

\begin{tabular}{|c|c|c|c|c|}
\hline \multirow[t]{2}{*}{ Kelompok } & \multirow[t]{2}{*}{$n$} & \multirow{2}{*}{$\begin{array}{c}\text { Rerata } \pm \text { SD } \\
(\mu \mathrm{g} / \mathrm{dl})\end{array}$} & \multicolumn{2}{|c|}{ Nilai } \\
\hline & & & Min & Max \\
\hline$A(F e+v i t A)$ & 29 & $19,1 \pm 4,66$ & 12,2 & 34,7 \\
\hline $\mathrm{B}(\mathrm{Fe})$ & 29 & $19,0 \pm 5,88$ & 11,8 & 32,1 \\
\hline C (Placebo) & 31 & $19,5 \pm 5,97$ & 9,8 & 32,5 \\
\hline
\end{tabular}

Dari Tabel 5 tampak bahwa rerata kadar vitamin A untuk ketiga kelompok penelitian masih rendah dan tidak ada perbedaan yang bermakna. Kelompok A sebesar 19,1 $\pm 4,66$ $\mu \mathrm{g} / \mathrm{dl}$, kelompok B sebesar 19,0 $\pm 5,88 \mu \mathrm{g} / \mathrm{dl}$ dan kelompok $C$ sebesar 19,5 $\pm 5,97 \mu \mathrm{g} / \mathrm{dl}$.

\section{Data Biokimia dan Konsentrasi Belajar setelah Intervensi}

Data biokimia setelah 3 bulan intervensi disajikan pada Tabel 6, 7 dan 8 .

Tabel 6

Rata-rata Kenaikan Kadar $\mathrm{Hb}$ sesudah intervensi menurut Kelompok

\begin{tabular}{cccc}
\hline Kelompok & $\mathrm{n}$ & $\begin{array}{c}\mathrm{Hb} \text { Akhir } \\
\text { Rerata } \pm \mathrm{SD}(\mathrm{g} / \mathrm{dl})\end{array}$ & Perubahan $\pm \mathrm{SD}$ \\
& & $12,6 \pm 0,6770$ & $1,4 \pm 0,79$ \\
$\mathrm{~A}$ & 47 & $12,4 \pm 0,6889$ & $1,2 \pm 0,62$ \\
$\mathrm{~B}$ & 45 & $11,9 \pm 0,9239$ & $0,4 \pm 0,25$ \\
$\mathrm{C}$ & 47 & $\mathrm{~F}=12,78$ & $\mathrm{~F}=39,67$ \\
& & Sign $=0,000$ & Sign $=0,000$ \\
\hline
\end{tabular}

Tabel 7 menunjukkan bahwa setelah intervensi 3 bulan rerata kadar $\mathrm{Hb}$ Kelompok $\mathrm{A}$ dan $B$ masing-masing naik sebesar 1,4 $\pm 0,79$ $\mathrm{g} / \mathrm{dl}$ dan $1,2 \pm 0,62 \mathrm{~g} / \mathrm{dl}$, sedangkan kelompok $\mathrm{C}$ yang tidak mendapatkan pil zat besi atau vitamin A juga terjadi kenaikan sebesar $0,4 \pm$ $0,25 \mathrm{~g} / \mathrm{dl}$. Kenaikan merupakan efek psykhologis dari plasebo, hal serupa juga ditemukan pada penelitian sebelumnya.

Tabel 7

Rerata Penurunan Kadar Transferin Sesudah Intervensi menurut Kelompok

\begin{tabular}{cccc}
\hline Kelompok & $\mathrm{n}$ & $\begin{array}{c}\text { STFR Akhir } \\
\text { Rataan } \pm \mathrm{SD}(\mu \mathrm{g} / \mathrm{L})\end{array}$ & Perubahan \pm SD \\
\hline $\mathrm{A}$ & 34 & $1,14 \pm 0,440$ & $-1,00 \pm 0,423$ \\
$\mathrm{~B}$ & 33 & $1,22 \pm 0,4582$ & $-1,03 \pm 0,469$ \\
$\mathrm{C}$ & 32 & $1,70 \pm 0,5900$ & $-0,37 \pm 0,385$ \\
& & $\mathrm{~F}=12,632$ & $\mathrm{~F}=24,499$ \\
& & Sign $=0,000$ & Sign $=0,000$ \\
\hline
\end{tabular}

Dari Tabel 7 di atas, terlihat ada perbedaan penurunan kadar transferin antara kelompok $A$ dan B masing-masing sebesar $1,0 \mu \mathrm{g} / \mathrm{L}$. Sedangkan kelompok $\mathrm{C}$ turun sebesar 0,37 $\mu g / L$. Penurunan kadar transferin menunjukkan adanya perbaikan. Dengan uji Anova ditemukan perbedaan yang bermakna dengan nilai $\mathrm{F}=$ 12,632 dan Sign $=0,000$. 
Tabel 8

Rata-rata Kenaikan Kadar Vitamin A Sesudah Intervensi menurut Kelompok

\begin{tabular}{cccc}
\hline Kelompok & N & $\begin{array}{c}\text { Vit.A Akhir } \\
\text { Rerata } \pm \text { SD }(\mu \mathrm{g} / \mathrm{dl})\end{array}$ & Perubahan \pm SD \\
\hline A & 24 & $24,7 \pm 5,2097$ & $6,1 \pm 4,99$ \\
B & 29 & $21,0 \pm 5,4019$ & $2,0 \pm 2,39$ \\
C & 31 & $22,6 \pm 7,9711$ & $2,0 \pm 5,69$ \\
& & $F=4,713$ & $F=7,20$ \\
& & Sign $=0,012$ & Sign $=0,001$ \\
\hline
\end{tabular}

Dari Tabel di atas terlihat bahwa kelompok A yang memperoleh kapsul Vitamin A dan pil zat besi 2 kali per minggu memberikan dampak yang paling tinggi terhadap kenaikan kadar Vitamin A sebesar $6,1 \pm 4,99 \mu \mathrm{g} / \mathrm{dl}$, dibandingkan dengan kelompok $B$ dan $C$ yang tidak memperoleh Vitamin A. Dengan uji Anova ditemukan perbedaan kenaikan yang bermakna dengan nilai $F=7,20$ dan Sign $=0,001$. Dari Tabel 9, terlihat bahwa konsumsi energi dan protein sebelum intervensi untuk ketiga kelompok penelitian masih rendah berkisar 50 55,9 persen dari angka kecukupan gizi (RDA). Konsumsi vitamin $A$, zat besi dan vitamin $C$ sebelum intervensi juga sangat rendah berkisar antara $36-44,4$ persen, 24,2-30,0 persen dan 26,0-40,0 persen masing-masing untuk vitamin A, zat besi dan vitamin C. Setelah intervensi tiga bulan ternyata konsumsi zat gizi untuk semua kelompok penelitian tidak jauh berbeda.

Tabel 9

Rerata Konsumsi Zat Gizi Sebelum dan Sesudah Intervensi menurut Kelompok

\begin{tabular}{lcccccc}
\hline \multirow{2}{*}{ Zat Gizi } & \multicolumn{3}{c}{ Sebelum Intervensi } & \multicolumn{3}{c}{ Sesudah Intervensi } \\
\cline { 2 - 7 } & $\mathrm{A}$ & $\mathrm{B}$ & $\mathrm{C}$ & $\mathrm{A}$ & $\mathrm{B}$ & $\mathrm{C}$ \\
\hline Energi (kkal) & $1036 \pm 314,2$ & $1027 \pm 315,1$ & $1036 \pm 311,3$ & $1045 \pm 285,0$ & $1045 \pm 338,1$ & $1008 \pm 366,9$ \\
$\%$ AKG & 51,8 & 51,4 & 51,8 & 52,3 & 52,3 & 50,4 \\
\hline Protein (g) & $32,4 \pm 15,17$ & $29,6 \pm 12,2$ & $33,4 \pm 10,7$ & $29,7 \pm 11,61$ & $31,8 \pm 8,8$ & $32,0 \pm 11,32$ \\
$\%$ AKG & 55,9 & 51,0 & 57,6 & 51,2 & 54,8 & 55,2 \\
\hline Vitamin A (RE) & $180 \pm 114,5$ & $222 \pm 187$ & $215 \pm 204,1$ & $198 \pm 105,5$ & $286 \pm 157,0$ & $220 \pm 141,4$ \\
$\%$ AKG & 36,0 & 44,4 & 43,0 & 39,6 & 57,2 & 44,0 \\
\hline Zat Besi (mg) & $4,2 \pm 2,0$ & $3,4 \pm 1,70$ & $3,6 \pm 1,57$ & $4,2 \pm 2,20$ & $3,3 \pm 1,56$ & $3,8 \pm 1,58$ \\
$\%$ AKG & 30,0 & 24,2 & 25,7 & 30,0 & 23,6 & 27,1 \\
\hline Vitamin C (mg) & $20 \pm 7,3$ & $17 \pm 10,5$ & $13 \pm 9,8$ & $15 \pm 11,80$ & $13 \pm 10,3$ & $22 \pm 12,2$ \\
$\%$ AKG & 40,0 & 34,0 & 26,0 & 30,0 & 26,0 & 44,0 \\
\hline
\end{tabular}

\section{BAHASAN}

Penelitian dilakukan dengan memenuhi kriteria suatu penelitian eksperimen, dilakukan secara "double blind", penentuan sampel dilakukan secara acak, dilakukan pemberian obat cacing sebelum dimulai perlakuan. Hasil penelitian menunjukkan pemberian pil zat besi yang diberikan bersamaan dengan pemberian kapsul vitamin A memberi pengaruh yang bermakna dibandingkan dengan plasebo. Defisiensi zat besi timbul bila cadangan dalam tubuh digunakan untuk memenuhi kebutuhan tubuh. Status besi ditentukan berdasarkan kadar $\mathrm{Hb}$ dan serum transferin reseptor (sTFR),

Status besi berdasarkan kadar $\mathrm{Hb}$ dan serum transferin reseptor (sTFR), status vitamin A(retinol) dan nilai konsentrasi belajar, sebelum pelaksanaan suplementasi antar ketiga kelompok tidak menunjukkan perbedaan yang 
bermakna. Kondisi awal seperti ini cukup ideal untuk mengamati pengaruh suplementasi, karena perubahan yang terjadi lebih disebabkan oleh suplementasi itu sendiri dan bukan disebabkan oleh faktor lain.

Setelah 12 minggu suplementasi dilakukan, terjadi kenaikan kadar $\mathrm{Hb}$ pada kelompok $\mathrm{A}$ yang mendapat suplementasi Fe + Vitamin A, sebesar 1,4 g/dl, lebih tinggi dari pada kelompok $B(1,2 \mathrm{~g} / \mathrm{dl})$ yang hanya mendapat $\mathrm{Fe}$ saja. Keunggulan kelompok $A$ sesuai dengan teori bahwa vitamin A dapat meningkatkan mobilisasi cadangan zat besi dalam hati (Zimmerman et al. 2004) ${ }^{4}$. Kenaikan kadar $\mathrm{Hb}$ yang cukup tinggi juga sejalan dengan tingkat kepatuhan mengkonsumsi suplemen yang mencapai lebih dari 80 persen.

Kenaikan kadar $\mathrm{Hb}$ pada kelompok pembanding yang mendapat plasebo diduga sebagai akibat "efek plasebo" dan pemberian tambahan energi sebesar 15 persen RDA dalam bentuk snack yang diberikan setiap kali sebelum siswa mengkonsumsi suplemen.

Hasil penelitian yang dilakukan oleh Mwanry et al, $2000^{\circ}$, menunjukkan pemberian kombinasi pil zat besi dan vitamin A menghasilkan peningkatan yang lebih baik pada kadar hemoglobin, penambahan berat badan dan peningkatan tinggi badan dibandingkan dengan yang hanya mendapat vitamin $\mathrm{A}$ dan placebo. Perubahan kadar hemoglobin setelah pelaksanaan suplementasi selama 3 bulan menunjukkan perubahan masing-masing pada kelompok yang hanya mendapat vitamin $A$ sebesar $1,35 \mathrm{~g} / \mathrm{dl}$, yang mendapat pil zat besi sebesar $1,76 \mathrm{~g} / \mathrm{dl}$ dan yang mendapat keduanya sebesar 2,21 g/dl.

Mengingat masih rendahnya asupan zat gizi termasuk konsumsi vitamin $\mathrm{A}$ maupun zat besi seperti yang ditunjukkan pada Tabel 9 dan risiko yang timbul akibat anemia, maka diperlukan pemberian tambahan zat besi pada kalangan anak sekolah dan akan lebih memberi hasil bila diberikan bersamaan dengan pemberian vitamin $\mathrm{A}$.

\section{SIMPULAN DAN SARAN}

\section{Simpulan}

1. Suplementasi zat gizi mikro (vitamin A dan $\mathrm{Fe}$ ) kelompok $\mathrm{A}$ dapat meningkatkan kadar $\mathrm{Hb}$ lebih tinggi dibandingkan dengan kelompok B yang hanya memperoleh pil besi saja.

2. Suplementasi vitamin A dan Fe (kelompok A) memberikan dampak positif terhadap perubahan kadar transferin sebagai indikator status besi pada anak sekolah.

\section{Saran}

Mengingat rata-rata konsentrasi belajar anak SLTP di pedesaan masih rendah, maka hasil penelitian ini dapat di implementasikan secara nasional sebagai muatan program upaya kesehatan sekolah untuk perbaikan konsentrasi belajar anak sekolah. Perlu digalakkan kembali kegiatan pemberian makanan tambahan anak sekolah (PMT-AS) yang dipadukan dengan suplementasi vitamin A dan pil zat besi yang diberikan selama 2 kali per minggu.

\section{UCAPAN TERIMA KASIH}

Terima kasih disampaikan kepada Kepala Badan Litbangkes, Kepala Puslitbang Gizi dan Makanan yang telah memberikan dana dan kesempatan untuk melakukan penelitian ini. Terima kasih disampaikan juga kepada Kepala Puskesmas Sukaraja dan Rancabungur yang telah membantu pemeriksaan kesehatan siswa SLTP. Terima kasih pula disampaikan kepada Kepala Sekolah MTs Fathusa'adah Sukaraja dan SLTP Purnawarman Rancabungur beserta para guru yang telah memberi izin dan membantu kelancaran pelaksanaan penelitian. Rasa terima kasih juga tak lupa disampaikan kepada anak-anak/siswa SLTP yang telah berpartisipasi pada penelitian. Ucapan terima kasih disampaikan juga pada Yayasan Bina Mandiri yang telah membantu pengumpulan data konsentrasi belajar siswa SLTP. Kepada semua pihak yang telah membantu terlaksananya penelitian ini yang belum disebutkan di sini, kami mengucapkan terima kasih banyak.

\section{RUJUKAN}

1. Departemen Kesehatan R.I. Laporan Hasil Riset Kesehatan Dasar (RISKESDAS), Jakarta: Badan Litbang Kesehatan, 2008

2. Departemen Kesehatan R.I. Survai Kesehatan Rumah Tangga (SKRT). Jakarta: Badan Litbang Kesehatan, 2001. 
3. Saidin dkk. Profil status gizi ,Kebugaran dan Prestasi Belajar pada Murid SMP. Laporan Penelitian. Bogor: Pusat Penelitian dan Pengembangan Gizi dan Makanan, 2009.

4. Wiryatmadji dkk. Laporan Survai WFP'S Nutrition Rehabilitation. Programme in Madura, Lombok and West Timor, Sept Nov. 2007. S.I: s.n, 2007.

5. Ke Chen, Xuan Zhang, Ting-Yu Li, Li Chen, Ping Qu, You-Xue Liu. Co-assessment of iron, vitamin $A$ and growth status to investigate anemia in preschool children in suburb Chongqing. China. World J Pediatr $2009 ; 5(4): 275-281$

6. Gamble MV, Palafox NA, Dancheck B, Ricks MO, Briand K, Semba RD. Relationship of vitamin A deficiency, iron deficiency, and inflammation to anemia among preschool children in the Republic of the Marshall Islands. Eur J Clin Nutr. 2002. Oct 58(10):1396-401

7. Zimmermann $M B$, Biebinger $R$, Rohner $F$, Dib A, Zeder C, Hurrell RF and Nourredine Chaouki. Vitamin A supplementation in children with poor vitamin $A$ and iron status increases erythropoietin and hemoglobin concentrations without changing total body iron. Am J Clin Nutr 2006;84:580-586.

8. Lemeshow et.al. Besar Sampel Dalam Penelitian Kesehatan. Yogyakarta: Gadjah Mada University Press, 2000.

9. Lillian Mwanri, Anthony Worsley, Philip Ryan and Joseph Masika. Supplemental Vitamin A Improves Anemia and Growth in Anemic School Children in Tanzania. J. Nutr. 2000, 130: 2691-2696. 